\title{
Communicative Approaches to Teaching Spoken English in Pre-service Teacher Education in EFL Contexts
}

\author{
Helen Jang \\ University of Leeds, England
}

\begin{abstract}
Following education policy and curriculum innovations for spoken English development, there have been changes as well as challenges in English classrooms in Korea in recent years. In line with the new government policy for pre-service English teacher education, this research explored the nature of teacher learning during the practicum. The aims of this study were to understand the student teachers' views and experiences of the classroom practice period with regard to the use and instruction of spoken English in English classrooms. This research employed two case studies in urban and rural contexts during the intensive period of the practicum. Data was generated by classroom observations in secondary schools and by in-depth interviews with the student teachers from the communicative perspectives. Contextual factors were taken into consideration in relation to their influence on how the student teachers perceived and conducted teaching of speaking in accordance with the curriculum policy mandated by the Ministry of Education. Based on the main findings of this research, implications were drawn to strengthen the relationships between education policy and classroom practice and school contexts. Suggestions were made as regards the effective ways to facilitate teaching and learning spoken English, reflecting the diversity and complexity of classroom contexts through context-sensitive approaches in EFL contexts.
\end{abstract}

Keywords: Communicative Approach, Spoken English, Pre-service Teacher Education, EFL Contexts, case study

\section{INTRODUCTION}

As a response to globalization, there have been education innovations in Korea to improve the quality of English education and English teacher education. In order to improve oral proficiency in English through school education, the government has introduced an education policy to recruit English teachers in 
Korea to teach speaking. There have also been gradual national curriculum reforms reflecting social changes and educational needs. However, while policy emphasizes the development of spoken English skills in schools, it has been noted that English teachers lack the required skills to teach English in English or to implement communicative pedagogy through task-based instruction because of lack of understanding of effective methodology to teach speaking. In line with recent education policy which aims to develop oral proficiencyand communicative pedagogy in school education, there is a need for more support for teachers through teacher education. Recently pre-service teacher education has been given more attention to better meet the new requirements for initial teacher preparation by increasing the emphasis on the role of actual practice as a measure of teacher quality.

As there is a paucity of research on teacher learning through initial teaching practice in relation to teacher cognition, particularly in the area of spoken English, this study explores pre-service English teachers' experiences during the practicum period, with a focus on teaching speaking. The study also considers the inter-relations between factors such as teacher training, teacher cognition, and teaching context.

\section{LITERATURE REVIEW}

\section{Teaching Practicum}

Research on teacher education has shifted emphasis in the last two decades. As most research on teacher training between the 1960s and 1970s was based on empirical research about effective teaching, it was not until the 1980s that teacher education research focused on teacher thinking or teacher learning. Teacher belief and knowledge were investigated in relation to classroom practice in order to understand teacher learning from the teacher cognition perspective (Borg, 2006).

In comparison to traditional views on teacher training, contemporary approaches focus on the process of teacher learning through inquiry-based (Nguyen, 2009) or research-based reflective practice (Kynäslahti et al., 2006). From the socio-cultural perspective, teacher learning is viewed as socially and culturally situated in classroom contexts (e.g. Freeman \& Johnson, 1998), whilst constructivists emphasize knowledge-building through critical reflection on practice and reconstruction of prior belief or knowledge (Richards \& Farrell, 2005).

Research reports the importance of field experience as an essential part of teacher learning in pre-service teacher education (Farrell, 2008). The teaching practicum plays a key role as a bridge between teacher preparation and the teaching career (Stanulis \& Russell, 2000), and student teachers' teaching 
practice was examined as a most effective tool in initial teacher training (Malderez \& Wedell, 2007). Teacher belief and practice seem to be influenced by the particular setting of classrooms and schools because teacher learning is socially situated and constructed in the context of teaching from socio-cultural perspectives (Rosaen \& Florio-Ruane, 2008). The socio-cultural context of teaching seems to foster or constrain classroom practice and the growth of practical knowledge, but there has been relatively little research on student teachers' initial teaching experience and their conceptualization of teaching in relation to the teaching context or the impact of teacher training in English teacher education (Darling-Hammond, 2006).

\section{Teaching Speaking}

Nowadays English is recognized as a world language in a global society and English has greater diversity in its style and status with a different sociolinguistic and political power (Quirk, 1985). Since English is viewed as an international language, to acquire communicative competence in English has been highly significant in teaching English (Canale \& Swain, 1980). According to Martinerz-Flor et al. (2006:139), speaking is 'an interactive, social, and contextualized communicative event,' and in order to fully understand communication processes, it seems important to understand the teaching and learning of speaking in classroom contexts, where meanings are socially negotiated and constructed (Gee, 2004).

To improve speaking skills in the classroom, it is necessary to provide students with opportunities to be exposed to speaking continuously in order for autonomous learning to take place. It is also crucial to create classroom contexts where students freely engage in communicative activities. Students practice speaking by engaging in communicative tasks. Structuring classroom discourses between the teacher and students is essential to transform linguistic knowledge into language use and balance spontaneous language use and language learning (Bygate, 2006). As Johnstone (1989) indicates, due to the limited potential for natural acquisition in the classroom environment, it is necessary to develop communicative competence by raising awareness of speech processing, that is, from conscious monitoring toward unconscious automation of speech.

In contemporary views of English language teaching (ELT), the principles of teaching speaking are based on learner-centered pedagogies, communicative approaches, and task-based frameworks. Communicative language teaching (CLT) evolved around the middle of the 1970s and developed rapidly throughout the 1980s as a new approach to language pedagogy with a shift of traditional methodology in ELT (Li, 1998). CLT has brought a shift from emphasis on grammar toward communicative competence through encouraging genuine and spontaneous language use in the classroom 
(Celce-Murcia et al., 1997). Task-based learning (TBL) as a branch of CLT focuses on language use in real life (Willis, 2004). To encourage purposeful target language use in meaningful contexts, students work on real life tasks with real life materials, exploring real life situations (Skehan, 2003). TBL prioritizes language practice with a language focus at the end of the lesson,to encourage language use beyond current competence (Thornbury, 2000). However, communication itself is not sufficient, and it is crucial to structure communication through task design (Bygate, 2006). Task interaction improves comprehension of input through the negotiation of meaning (Pica et al., 1987) and task repetition also promotes speech development through input enhancement (Bygate, 2006; Lynch \& Maclean, 2000). It seems also to be essential to train students in communicative strategies, cooperative or collaborative learning strategies, and interactive or interpersonal strategies (Lam \& Wong, 2000; O'Malley \& Chamot, 1990) by providing supportive learning environments with a consideration of learner characteristics and particular contexts as learners' cognitive and affective factors influence language learning (e.g. Dörnyei \& Kormos, 2000).

Despite its advantages, however, CLT has been criticized for theoretical and methodological problems for pedagogical implementations and educational innovations in a wider range of educational contexts (e.g. Burnaby \& Sun, $1989 ; \mathrm{Li}, 1998$ ). One of the main problems of CLT in EFL (English as a Foreign Language) contexts is related to existing educational systems centered on grammar-based examinations $(\mathrm{Li}, 1998)$ and socio-cultural expectations of preparation for grammar-based examinations in the classroom (Carless, 2004). There has also been a debate about the frequent use of the mother tongue in EFL classrooms (Swain \& Lapkin, 2000).

Spoken English is one of the language skills that is under researched (Hughes, 2002). There has been a paucity of research on teaching speaking in relation to teacher cognition and practice (Borg, 2006) or pre-service teacher education. There is a need for more research on the teaching of spoken English particularly in EFL contexts.

\section{METHOD}

\section{Participants}

The participants were selected from $4^{\text {th }}$ year student teachers in teacher colleges in Korea through purposive sampling. Preliminary questionnaires were distributed to the final year student teachers who were majoring in English education, and potential participants were identified amongst those who were willing to participate in the study. After initial meetings with those who showed interest in the study, two participants were selected with a 
20 | ELT Worldwide Vol. 1 No.

consideration of logistics and the research focus. To maintain confidentiality, pseudo-initials were also employed for the participants.

Student teacher J took the practicum in a secondary school in the capital city. He was 26 years old, and had neither study abroad experience, nor previous teaching experience, apart from a little private teaching of his nephews. He taught lower level classes in the $2^{\text {nd }}$ grade. Student teacher E took the practicum in her old secondary school in a small city. She was 24 years old, and had learned English in Canada. Apart from teaching her sisters, she also had no previous teaching experience. She taught students in the $1^{\text {st }}$ grade and in the $3^{\text {rd }}$ grade in mixed level classes which were not streamed.

\section{Data Collection}

Data was collected using mixed methods. There was a preliminary questionnaire distributed to the $4^{\text {th }}$ year student teachers specializing in English education as a preparatory source of information, and subsequent interviews followed with the student teachers who participated in the study as primary data. There were four semi-structured interviews with each student teacher. The initial interview aimed at understanding the student teachers' prior knowledge or understanding of teaching speaking before the practicum. During the practicum, there were pre-observation interviews after the student teachers observed teachers. Post-observation interviews were conducted after observing the student teachers. There were also follow-up interviews to reflect on their learning and whether there was any change or development in their cognition after the practicum.

Observations were conducted for two weeks. Once student teachers started to teach, observation schedules were discussed, and as they taught only a few lessons and as most lessons were centered on written skills, two or four lessons were observed in each school with a particular focus on teaching of spoken skills in the textbook. Interviews and observations were recorded and transcribed to help to retrieve the data.

\section{Data Analysis}

Interview data were analyzed by thematic analysis based on grounded theory. The analysis proceeded following a series of coding, that is, from the initial stage of identifying major themes by a line-by-line approach, through categorizing common themes or linking emerging themes in relation to the research questions, toward integrating concepts and theories at the final stage (Strauss and Corbin, 1990). Observation field-notes were analyzed by developing codes from the patterns of pedagogical or socio-cultural themes to be compared with interview data for triangulation (Miles \& Huberman, 
Jang, Communicative Approaches in Teaching Spoken English $\mid \mathbf{2 1}$

1994). All the data was fully transcribed and translated in English and classroom English was italicized using quotation marks.

\section{RESULTS}

Student teachers' perspectives and practices of teaching speaking were explored by comparing data before, during, and after the practicum. Some of the major factors which interacted with their learning during the practicum were embedded in the context of their individual schools because their experiences during the practicum were bound to their school contexts. There was also some evidence of a positive influence of teacher training on their practice in relation to employing elicitation strategies to interact with the students with an emphasis on communicative teaching. Key findings of this study are discussed below.

\section{Nature of Elicitation Strategy and Oral Practice}

Student teacher E taught a class of mixed level students in a large classroom, a typical setting in a traditional lower secondary school in Korea. She frequently employed questions to elicit responses from the students. She addressed questions either by making personal examples or by using pictures in the textbook as a warm-up activity before her lesson, and to review key expressions after her lesson. This kind of activity was carried out with the class as a whole. The students answered using the expressions in the textbook:

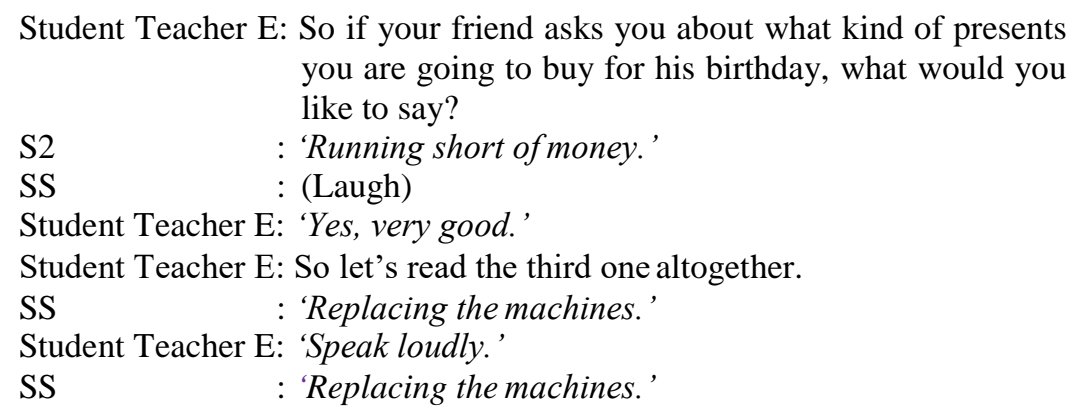

In her lessons, reading aloud was preferably adopted as seen in the example above, and the students read aloud according to her instruction for oral practice after listening. During speaking practice for the section 'Let's Talk' in the textbook, again she asked the students merely to read aloud the model dialogue with a focus on pronunciation. After the whole class read aloud as a group, speaking practice was carried out in pairs by a number of volunteer students. The students seemed to participate in pair work very actively, but this was again very controlled oral practice based on the expressions in the textbook. Her controlled speaking practice using the model dialogue did not seem to 


\section{2 | ELT Worldwide Vol. 1 No. 1}

engage the students in natural speech. They merely repeated short speech segments from the textbook. Moreover, she mostly used Korean for classroom instruction, except when she was quoting the textbook, or occasionally when she responded to the students' answers but only in short and simpleEnglish.

\section{Use of the Mother Tongue and Classroom Interaction}

Student Teacher $\mathbf{J}$ taught a class of low-level students as his school was streamed by the students' proficiency in English according to the national curriculum. During his lessons, he seemed to encourage classroom interaction by frequently having chats or making jokes with the students. His interactive strategy seemed to reflect his initial views of the importance of building up rapport and a good relationship with the students in order to encourage communicative interaction. However, he rarely used classroom English, though this seemed to reflect his understanding of the level of the students. He also provided much spoken input by playing the tape frequently for the students to become familiar with listening, instead of speaking. His main elicitation strategy was to ask very short questions repetitively in order to elicit answers in English from the students using the textbook, but this was not always eliciting English from the students but merely translating the meaning of the expressions in Korean as shown below:

Tape: 'There are many kinds of life on the earth...'

Student Teacher J: 'There are?'

S1: (Shout) There is something...

Student Teacher J: Yes. Right. This means, there is something.

Student Teacher J: There are what?

SS: (Shout) Many kinds, many kinds of life, animals...

Student Teacher J: Yes. Right.

Student Teacher J: Where?

SS: (Shout) On the earth.

Student Teacher J: What do scientists want?'

S1: (Shout) 'To go to this planet.'

Student Teacher J: Yes. Right.

Student Teacher J: Where do they want to go?

SS: 'Mars.'

There was much vocabulary practice or grammar practice instead of speaking practice, but he seemed to try to elicit English from the students by making further examples, based on altering the grammatical patterns in the textbook. Though this activity seemed to provide the students with more chances for oral practice based on vocabulary or grammar in the textbook, it did not engage the students in communicative practice. He usually employed reading 
Jang, Communicative Approaches in Teaching Spoken English $\mid \mathbf{2 3}$

aloud as oral practice after listening and let the students repeat the expressions in the textbook as a single group.

To sum up, the teaching of speaking skills during the practicum was limited to oral practice by reading aloud some segments of the textbook. The student teachers rarely used classroom English, nor were they teaching English in English (TEE) in line with government policy. Though their practice showed their efforts to some extent, to apply what they learned from teacher training to their lessons in the teaching of speaking skills by making use of elicitation strategies such as praise or a stimulus, there was not much speaking practice amongst the students. There was no speaking practice through negotiation of meaning in communicative interaction. Their practice of English teaching seemed to indicate how the impact of teacher training was constrained by the context of teaching.

\title{
Prior Cognition and Understanding of the Context
}

Drawing on her childhood experience of studying English abroad, student teacher E was very positive and confident about teaching speaking using communicative approaches. During the practicum, her understanding of CLT grew by connecting theory with practice while interacting with the students and gaining more knowledge of the students' characteristics. However, her practice was constrained by the school education system. Because the students in her class were not streamed according to their level, she confronted difficulties in her mixed level class. Her perception of the role of the native teacher and textbook-based school education also constrained her practice, and her communicative approach had to be based mainly on oral practice of the dialogue in the textbook:

\begin{abstract}
I used the same expression in the textbook for speaking practice, because if I want to let them practise speaking with other expressions, I have to make my own multimedia materials for the speaking activities by myself, and I could do that without any difficulty, but why I felt a bit uncertain about this was, in fact, the speaking section is taught by the native teacher. [...] If I teach this again, they may feel bored. Moreover as for the expressions in the textbook, I don't have to write them down on the blackboard because they are already written, so it saves me much time to teach speaking while I have to teach other sections in the textbook. I planned to do only one part in the speaking section but I decided to let them do all of them today...
\end{abstract}

As for student teacher $\mathrm{J}$, the main difficulty in teaching speaking was caused by the poor oral proficiency of the students in the low-level class, though his class was streamed. It was a challenge for him to control naughty students, who often were unmotivated because of their low ability as well as low proficiency, but he seemed to try to employ his student-centered strategy for classroom management as he initially planned by using praise frequently. However, he still found difficulty in supporting those who had benefited from private tuition and were advanced compared to the others. 


\section{4 | ELT Worldwide Vol. 1 No. 1}

This contributed to the gap in the proficiency level amongst the students in the class.

\section{Mentor Influence and Learning of Practice}

Moreover, student teacher $\mathbf{J}$ felt that his approach to teaching spoken English was frustrated by pressure from his mentor because his mentor had commented on his practice urging him to focus on the textbook and prepare for the exam:

So my mentor said to me, rather than explaining each word's meaning one by one, to try to speed up. [...] Therefore, he said it is better to cover the scope of the textbook, so that the students can feel that they finished the textbook before the exam.

He felt that his mentor was not fluent in speaking, and, therefore, not supportive of communicative practice. Moreover, he was also not very confident about his own fluency and his ability to teach his class in English. He perceived a dilemma between theory and practice arising from his lack of teaching skills and from the students' poor motivation and proficiency during his attempt to teach speaking. However, at the end of the practicum he seems to have increased his awareness of the school context and the education system. His understanding of CLT seems to have been practically modified by his experience in his school. That is, his approach to spoken English had to be adjusted in accordance with his perception of the students and the context factors:

I think, about 30 percent had got good understanding and followed the lesson very well, and about 20 percent were willing to follow the lesson but lacked overall understanding, and the rest half of the class understood nothing about English so I also gave them up in the end... for me every lesson was like that during the practicum. [...] Grammar should be taught first before speaking, otherwise, it is quite hard for them to start with speaking... I think it must also be important to let them speak again and again repetitively...

On the other hand, student teacher E was strongly supported by her mentor in teaching speaking skills. Her practicum seems also to have been influenced by her mentor, to some extent, in the ways that she implemented communicative activities. She encouraged every student's voluntary participation in speaking practice through peer competition as her mentor did. A stimulus using candy was her inclusive strategy to direct the off-task students' attention to 
speaking practice. She also preferred to adopt a short quiz game to increase the students' motivation in speaking practice.

Not because teaching speaking or communicative activity design is too difficult for me, but because it may be a bit too much if I teach speaking for a long time. [...] So I tend to implement speaking together with other language skills in the textbook. I usually do speaking activities briefly, from time to time, in the middle of each section throughout the lesson in the manner of doing a quiz or a game...

During the interviews, she showed her sensitivity to the students' individual needs and explained how she reflected the students' psychological factors in her strategy for teaching speaking. She had gained deeper understanding of the students throughout the practicum. It was also noted that her emphasis on increasing the students' participation for successful teaching of speaking skills seems to have been influenced by her own experience of struggles when she had to learn speaking. After the practicum, she also indicated the difficulties caused by teaching in her large class although she wanted to involve more students in her speaking activity. However, she stressed how her practice during the practicum shifted her views of CLT.

Before I went to the practicum, my views on CLT were, well, say, rather academic, based on teacher training that I received. Before the practicum, obviously I haven't got any teaching experience in the classroom, my views about teaching speaking or CLT were very ideal, I mean, I was thinking of CLT like a few students gather and then speak, but when I actually went to the classroom, and saw the students during the communicative activity, I got to know that making them able to participate in the communicative activity was in itself actually very much effective to enable them to speak, and my perspectives on how to approach CLT or teach speaking are now quite different from before.

Her views of CLT seem to have changed according to her students' response during the practicum. She evaluated the impact of her practice teaching on her learning experience very positively. However, her perception of CLT was not always consistent with her practice, as her practice of CLT did not encourage communicative practice but merely oral practice, while various variables had influenced her practice in her classroom and school context.

\section{DISCUSSION AND CONCLUSION}

This study explored two student teachers' perspectives and practices during the practicum. It was aimed at investigating the factors which may have affected their views and experiences of teaching speaking while they were applying theory to practice by learning to teach in their classrooms. 


\section{6 | ELT Worldwide Vol. 1 No. 1}

The student teachers' personal English language preparation from their childhood English language learning experiences and teacher training, as well as the various supportive or hindering aspects of the school contexts during the practicum, seem to have had an impact on their learning.

The intensive period of the practicum seemed to contribute, to some extent, to enhancing their learning and their understanding of appropriate and effective methods of teaching speaking to their students. However, as the findings showed, teaching a few lessons for a short period was not enough for the student teachers to make sense of their experience and reconstruct their knowledge base for teaching. In particular, under the pressure caused by the exam-centered and textbook-based education system, there was a significant lack of time for them to teach speaking skills effectively. Support from the mentor and the school was also important in enabling the student teachers to become settled in the context of teaching and to develop their own teaching skills beyond contextual constraints by actively engaging in teaching and socializing in the classroom. Nevertheless, given that there was no support provided by the teacher colleges during the practicum, student teachers' learning from the practicum was limited and bound to their school context or personal qualities.

From this study, implications are drawn for the development of pedagogy and methodology for teaching speaking, and also pre-service teacher training in EFL contexts. This study suggests the importance of developing communicative approaches for the classroom and school contexts in EFL countries and the need to increase the understanding of contextual factors. Only in this way can there be effective applications in material development and communicative task development, reflecting the perspectives of the teachers and the students. It seems important to make a context-sensitive communicative approach by considering motivational and cultural factors as well as educational systems in EFL contexts. Certainly, it has been reported that misconceptions about CLT amongst teachers cause them to make less effective use of CLT (e.g. Celce-Murcia et al., 1997). It should also be considered that the efficient use of the mother tongue could support TEE (e.g. Swain \& Lapkin, 2005; Wigglesworth, 2003). This study also demonstrates the need to develop further teacher training programs and support systems for the practicum, thus narrowing the gap between theory and practice and between policy and reality.

Though this study contributes to the understanding of teacher learning during the practicum, there is a limitation in that there were a small number of participants and observations of the classrooms due to the short intensive period of the practicum in Korea. Thus, the results of this study should not be generalized as the findings of qualitative research could be specific to particular contexts. There is a need for further research on the teaching practicum through more empirical and longitudinal studies in the diverse educational contexts of EFL countries. 
Jang, Communicative Approaches in Teaching Spoken English $\mid 27$

\section{REFERENCES}

Borg, S. (2006). Teacher cognition and language education. London: Continuum.

Burnaby, B. \& Sun, Y. (1989). Chinese teachers' views of Western language teaching: Context informs paradigm. TESOL Quarterly, 23(2), 219238.

Bygate, M. (2006). Areas of research that influence L2 speaking instruction, in Usó-Juan, E. \& Martinez-Flor, A. (eds.) Current trends in the development of teaching of the four skills. 159-186. Berlin: Mouton de Gruyter.

Canale, M. \& Swain, M. (1980). Theoretical bases of communicative approaches to second language teaching and testing. Applied Linguistics, $1(1), 1-47$.

Carless, D. (2004). Issues in teachers' reinterpretation of a task-based innovation in primary schools. TESOL Quarterly, 38(4), 639-662.

Celce-Murcia, M., Dörnyei, Z. \& Thurrell, S. (1997). Direct approaches in L2 instruction: A turning point in communicative language teaching? TESOL Quarterly, 31(1), 141-153.

Darling-Hammond, L. (2006). Constructing $21^{\text {st }}$ century teacher education. Journal of Teacher Education, 57(3), 300-314.

Dörnyei, Z. \& Kormos, J. (2000). The role of individual and social variables in oral task performance. Language Teaching Research, 4(3), 275-300.

Farrell, T. S. (2008). 'Here's the book, go teach the class': ELT practicum support. RELC, 39(2), 226-241.

Freeman, D. \& Johnson, K. E. 1998. Reconceptualizing the knowledge-base of language teacher education. TESOL Quarterly, 32(3), 397-417.

Gee, J. P. (2004). Learning language as a matter of learning social languages within discourses, in M. R. Hawkins (ed.) Language learning and teacher education: A sociocultural approach. (pp.13-31). Clevedon, UK: Multilingual Matters.

Hughes, R. (2002). Teaching and researching speaking. London: Pearson.

Johnstone, R. (1989). Communicative interaction: A guide for language teachers. London: CILT.

Kynäslahti, H., Kansanen, P., Jyrhämä, R., Krokfors, L., Maaranen, K. \& Toom, A. (2006). The multimode programme as a variation of researchbased teacher education. Teaching and Teacher Education, 22(2), 246256. 
Lam, W. \& Wong, J. (2000). The effects of strategy training on developing discussion skills in an ESL classroom. ELT Journal, 54(3), 245-255.

Li, D. (1998). "It's always more difficult than you plan and imagine": Teachers' perceived difficulties in introducing the communicative approach in South Korea. TESOL Quarterly, 32(4), 677-703.

Lynch, T. \& Maclean, J. (2000). Exploring the benefits of task repetition and recycling for classroom language learning. Language Teaching Research, 4(3), 221-250.

Malderez, A. \& Wedell, M. (2007). Teaching teachers: Processes and Practices. London: Continuum.

Martinez-Flor, A., Usó-Juan, E. \& Alcón Soler, E. (2006). Towards acquiring communicative competence through speaking, in Usó-Juan, E. \& Martínez-Flor, A. (eds.) Current trends in the development and teaching of the four language skills. (pp. 139-58). Berlin: Mouton de Gruyter.

Miles, M. B. \& Huberman, A. M. (1994). Qualitative data analysis: A Sourcebook of new methods. Thousand Oaks, CA: Sage.

Nguyen, H. T. (2009). An inquiry-based practicum model: What knowledge, practices, and relationships typify empowering teaching and learning experiences for student teachers, cooperating teachers and college supervisors? Teaching and Teacher Education, 25(5), 655-662.

O’Malley, J. M. \& Chamot, A. U. (1990). Learning strategies in second language acquisition. Cambridge: CUP.

Pica, T., Young, R. \& Doughty, C. (1987). The impact of interaction on comprehension. TESOL Quarterly, 21(4), 737-58.

Pica, T., Kanagy, R. \& Falodun, J. (1993). Choosing and using communication tasks for second language instruction, in Crookes, G. \& Gass, S. (eds.) Tasks and learning: Integrating theory and practice. 9-34. Clevedon: Multilingual Matters.

Quirk, R. (1985). The English language in a global context, in Quirk, R. \& Widdowson, H. G. (eds.) English in the world: Teaching and learning the language and literatures. (pp. 1-6). London: CUP.

Richards, J. C. \& Farrell, T. S. C. (2005). Professional development for language teachers. New York: CUP.

Rosaen, C. \& Florio-Ruane, S. (2008). The metaphors by which we teach: Experience, metaphor, and culture in teacher education, in CochranSmith, M., Feiman-Nemser, S., McIntyre, J. \& Demers, K.D. (eds.) Handbook of research on teacher education: Enduring questions in changing contexts. ( ${ }^{\text {rd }}$ edition). (pp. 706-731). London: Routledge. 
Skehan, P. (2003). Task-based instruction. Language Teaching, 36(1), 1-14.

Strauss, A. L. \& Corbin, J. (1990). Basics of qualitative research: Grounded theory procedures and techniques. London: Sage.

Stanulis, R. N. \& Russell, D. (2000). Jumping in: Trust and communication in mentoring student teachers. Teaching and Teacher Education, 16(1), 65-80.

Swain, M. \& Lapkin, S. (2005). The evolving sociopolitical context of immersion education in Canada: Some implications for program development. International Journal of Applied Linguistics, 15(2), 169186.

Swain, M. \& Lapkin, S. (2000). Task-based second language learning: The uses of the first language. Language Teaching Research, 4(3), 251- 274.

Thornbury, S. (2000). Accuracy, fluency and complexity. English Teaching Professional, 16, 3-6.

Wigglesworth, G. (2003). Bilingual initiatives in the ESL classroom, in Wigglesworth, G. (ed.) The kaleidoscope of adult second language learning: Learner, teacher and researcher perspectives. (pp. 221-247). Sydney: National Centre for English Language Teaching and Research, Macquarie University.

Willis, J. (2004). Perspectives on task-based instruction: Understanding our practices, acknowledging our different practitioners, in Leaver, B. L. \& Willis, J. (eds.) Task-based instruction in foreign language education. (pp. 3-44). Washington, D. C.: Georgetown University Press. 